\title{
CURRENT PRACTICES OF PERSONAL PROTECTIVE EQUIPMENT IN OPERATION THEATERS: A CROSS SECTIONAL STUDY
}

\author{
Saira Mahboob, Tariq Mehmood, Amna Gulrez*, Anum Sultan**, Zeshan Nasir, Taimur Azam Khan*** \\ Pakistan Naval Ship, Shifa Karachi Pakistan, * Pak Emirates Military Hospital/National University of Medical Sciences (NUMS) Rawalpindi \\ Pakistan, ${ }^{* * N a t i o n a l ~ H o s p i t a l ~ a n d ~ M e d i c a l ~ C e n t e r ~ L a h o r e ~ P a k i s t a n, ~}{ }^{* * * 72}$ Medical Battalion Malakand Pakistan
}

\begin{abstract}
Objective: To evaluate the prevailing practices regarding personal protective equipment in operation theaters. Study Design: Cross-sectional study.

Place and Duration of Study: Pakistan Naval Ship Shifa Hospital, Karachi, from May to Jun 2020.

Methodology: After the approval of the approval of the hospital ethical committee, 300 online forms were send. A total of 227 respondents returned the 22 questions survey forms. Data was collected and analyzed using online site www.surveyplanet.com.

Results: A total of 203 forms were included in our final analysis. Most 128 (63.1\%) were males with 90 (44.3\%) common aged between 31-40 years and $168(82.8 \%)$ working in tertiary care hospitals. One hundred and fifty eight $(77.8 \%)$ were routinely managing known Covid cases per-operatively. One hundred and seventy four $(85.7 \%)$ reported that personal protective equipment was being provided by the hospital administration; 55 (27.1\%) have bought part of full protective equipment at their own expense; 72 (35.5\%) re-using protective equipment; 167 (82.3\%) being provided with N-95 masks and 120 (59.1\%) re-using N-95 masks. One hundred and twenty one (59.6\%) wearing level III protective gear during all surgeries, 192 (94.6\%) respondents reported maintaining hand hygiene after each patient. Only 65 (32\%) taking shower at the hospital at the end of their shift. Conclusion: Most of the operation theaters were providing protective equipment to their staff with nearly half reusing protective gear and N-95 masks.
\end{abstract}

Keywords: Hand hygiene, Hand wash, N-95 masks, Personal protective equipment, Re-use.

\footnotetext{
This is an Open Access article distributed under the terms of the Creative Commons Attribution License (http://creativecommons.org/licenses/by/4.0), which permits unrestricted use, distribution, and reproduction in any medium, provided the original work is properly cited.
}

\section{INTRODUCTION}

Pakistan has over 560,000 diagnosed cases of COVID-19 with over 12,200 deaths with 2.2\% fatality rate ${ }^{1}$. The healthcare workers $(\mathrm{HCW})$ are increasing being infected with the virus ranging from $15-18 \%$. This can be attributed to inadequate use and availability of personal protective equipment (PPE) and diagnostic tests; lack of understanding of the disease and psychological stress ${ }^{2}$. International guidelines have been formulated on all the aspects of medical facilities including architectural and engineering requirement for ward and intensive care units (ICU); regulating the healthcare workers working in COVID-19 designated ICU and operation theaters; judicious use of personal protective equipment (PPE) and respirators. During the COVID-19 pandemic, acute

Correspondence: Dr Saira Mahboob, SD\#154, Lane\#6, Askari-V, Gulberg-III, Lahore Pakistan

Received: 23 Jun 2020; revised received: 18 Aug 2020; accepted: 20 Aug 2020 shortage of PPE is also been experienced by healthcare providers globally. Various societies have updated their guidelines for PPE use in the perioperative period ${ }^{3,4}$. Various strategies can be employed to mitigate this shortages. Firstly, the government and non-government welfare organization can increase the manufacturing of various components of PPE including gown, masks, goggles, face-shields and N-95 mask and respirators in Pakistan. Secondly, judicious use of PPE has been advocated. Thirdly, extended use and re-use of PPE and N-95 can be done under strict conditions ${ }^{5,6}$.

Fever $(98.6 \%)$, fatigue $(69.6 \%)$, dry cough and diarrhea are the more common presenting complaints with $81 \%$ patients having mild disease $^{7}$. However, asymptomatic and pre-symptomatic patients may be presenting to OT for nonCOVID related surgeries. The asymptomatic patients as well as OT staff may be a source of noso- 
comial spread of the disease. Most hospitals across Pakistan have COVID-19 dedicated OT working separately. However, level III PPE are recommended inside all operation theaters as OT are considered to be at high risk of transmission of this airborne virus; with aerosol generating procedures like oxygen therapy, intubations and extubation; being performed regularly in $\mathrm{OT}^{8,9}$.

The hospitals world-over experienced an acute shortage of PPE in the initial phase of the pandemic due to surge in demand and limited supply of PPE. This had made the healthcare workers un-easy and apprehensive about their own and other patients' safety. However, over time, the supply has improved with judicious provision of PPE to all hospital staff. The purpose of this study was to evaluate the present day practices regarding the PPE in OT across Pakistan to help formulate a regional policy regarding this.

\section{METHODOLOGY}

After the approval of the hospital ethical committee (ERC/2020/ANS/19), this cross-sectional study was conducted at Department of Anesthesiology, PNS Shifa Karachi, from May to June 2020. WHO sample size calculator was used to calculate a sample size of 273 , taking $77 \%$ usage of gown in healthcare workers ${ }^{10}$. A total of 300 online questionnaire were forwarded to healthcare workers working in various operation theaters across the Pakistan. The questionnaire consisted of 22 self-administered questions which were filled by doctors, nursing staff and operation room assistants. Participants who worked in the operation theater and willing to participate were included in our study by convenience sampling. The survey questionnaire was generated using online software www.surveyplanet.com and data was analyzed using SPSS version 20 . Qualitative data was presented as frequency and percentage. Quantitative data was presented as mean and standard deviation.

\section{RESULTS}

A total of 300 participants were sent the online porfoma via social media with 227 (75.6\%) respondents returning their porforma. Ten were excluded form study as they were filled by respondents who were not working in OT during covid pandemic; 15 were excluded as they were filled by participants outside of Pakistan and 2 were filled incompletely. So our final analysis was done with 202 responses. The demographic profile is shown in table-I. The diagnostic test being routinely done in perioperative period at various institutes are shown in table-II.

One hundred and seventy four (85.7\%)

Table-I: Demographic profile of study population.

\begin{tabular}{|c|c|c|}
\hline \multicolumn{2}{|l|}{ Variable } & n (\%) \\
\hline \multirow{2}{*}{ Gender } & Male & $128(63.1)$ \\
\hline & Female & $73(36)$ \\
\hline \multirow{4}{*}{ Age (years) } & $<30$ & $71(35)$ \\
\hline & $31-40$ & $90(44.3)$ \\
\hline & $41-50$ & $27(13.3)$ \\
\hline & $>51$ & $12(5.9)$ \\
\hline \multirow{3}{*}{ Level of Hospital } & Primary & $7(3.4)$ \\
\hline & Secondary & $24(11.8)$ \\
\hline & Tertiary & $168(82.8)$ \\
\hline Managing COVID- & Yes & $158(77.8)$ \\
\hline 19 cases routinely? & No & $41(20.2)$ \\
\hline \multicolumn{3}{|c|}{ Table-II: Test performed in perioperative period. } \\
\hline \multicolumn{2}{|c|}{ Variable } & n (\%) \\
\hline \multirow{3}{*}{$\begin{array}{l}\text { Is COVID-19 } \\
\text { Polymerase Chain } \\
\text { Reaction being done } \\
\text { routinely } \\
\text { preoperatively in } \\
\text { elective cases? }\end{array}$} & & \\
\hline & Yes & $131(64.5)$ \\
\hline & No & $62(30.5)$ \\
\hline \multirow{3}{*}{$\begin{array}{l}\text { Is COVID-19 } \\
\text { Polymerase Chain } \\
\text { reaction being done } \\
\text { routinely } \\
\text { postoperatively in all } \\
\text { emergency cases? }\end{array}$} & & \\
\hline & Yes & $112(55.2)$ \\
\hline & No & $78(38.4)$ \\
\hline \multirow{4}{*}{$\begin{array}{l}\text { Is High Resolution } \\
\text { Computed } \\
\text { Tomographic test } \\
\text { Chest being done in } \\
\text { surgical patients? }\end{array}$} & $\begin{array}{c}\text { Only if } \\
\text { symptomatic }\end{array}$ & $62(30.5)$ \\
\hline & $\begin{array}{l}\text { Only if high } \\
\text { suspicion of } \\
\text { COVID-19 }\end{array}$ & 81 (39.9) \\
\hline & $\begin{array}{l}\text { Only for } \\
\text { general } \\
\text { anesthesia } \\
\text { cases }\end{array}$ & $5(2.4)$ \\
\hline & $\begin{array}{l}\text { All surgical } \\
\text { cases }\end{array}$ & 31 (15.2) \\
\hline
\end{tabular}


participants reported that PPE were provided to all the HCW working in the operation theaters at their institute. Fifty five (27.1\%) respondents reported that they had to purchase full or part of PPE from their own pocket. One hundred and twenty seven $(62.6 \%)$ reported that PPE were single use only. The various method of sterilization/disinfection of PPE is shown in fig-1.

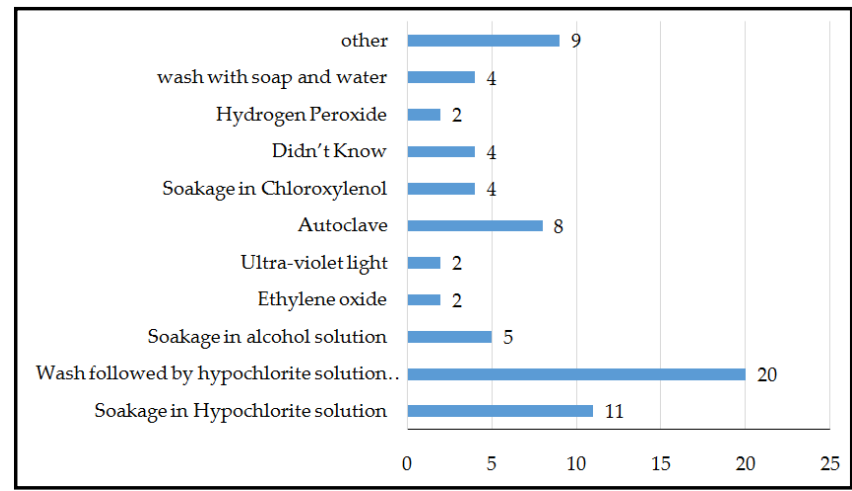

Figure- 1: Methods of PPE sterilization / disinfection.

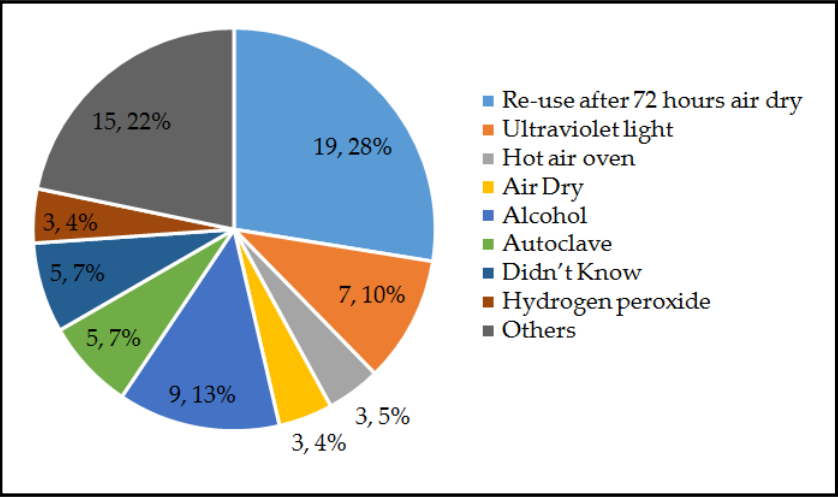

Figure-2: Method of sterilization of n-95 before use.

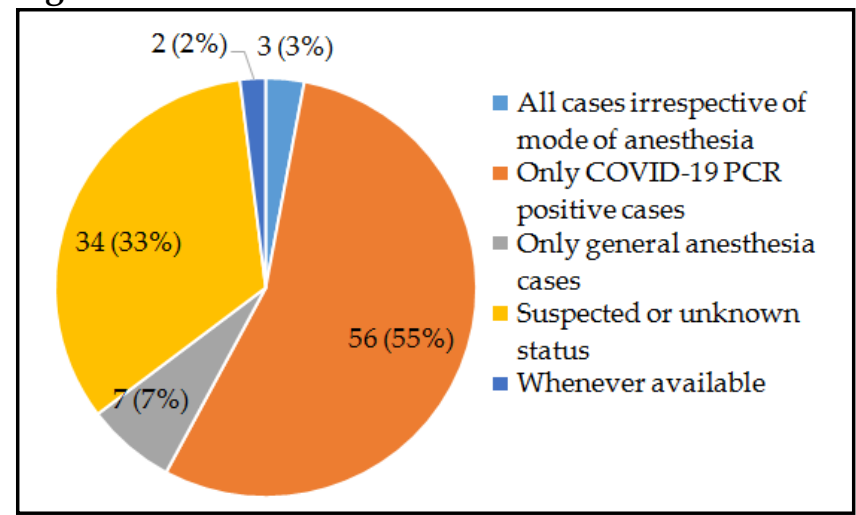

Figure-3: Situation of level III used in operation theaters.

One hundred and sixty seven (82.3\%) reported that N-95 masks are being provided to all HCW in OT. One hundred and twenty (59.1\%) reported re-use of $\mathrm{N}-95$. The methods used for sterilization/disinfection of N-95 are shown in fig-2. One hundred and twenty one (59.6\%) reported that level III PPE (gown, gloves, mask, goggles and face shield) were being used during all surgical cases, irrespective of COVID-19 status. The use of level III PPE for various situation is shown in fig-3.

One hundred and ninty two (94.6\%) reported that they maintained hand hygiene after every patient contact. One hundred and sixty two $(79.8 \%) \mathrm{HCW}$ washed their hands with soap and water for at least 20 second a mean of $13.6 \pm 10.3$ times in an eight hour duty shift. 65 (32\%) respondents reported that they showered at the hospital at the end of their shift. Sixty seven (33\%) reported that they had no facility of showering at their operation theater at their institutes.

\section{DISCUSSION}

The main mode of transmission of COVID-19 virus is airborne with face covering preventing its spread by blocking atomization and inhalation of virus as well as transmission by blocking contact with virus shedding droplets ${ }^{11,12}$. However, the virus may be aerosolized with sneezing and coughing; oxygen therapy; intubation, open suctioning and extubation ${ }^{13}$. Similarly, contact transmission via fomites has also been described ${ }^{14}$. This exposes the operating room personnel to increased viral load. In the setting of a low resource country like Pakistan with limited testing capabilities along with the possibility of transmission from pre-symptomatic carriers; the risk to $\mathrm{HCW}$ in operating rooms is magnified. A systematic review showed that respirators if worn continuously during a shift by HCW were effective against respiratory transmissible viruses ${ }^{15}$.

Pakistan healthcare system has been fighting the COVID-19 pandemic for 4 months now. The initial shortage of PPE has been met with increased indigenous production, continued supply chain, judicious use of PPE. According to authors' knowledge limited data have been done on practices regarding PPE during the present pandemic. 
This study has shown that $85.7 \%$ and $82.3 \%$ of HCW in operation theaters across Pakistan were being provided with PPE and N-95 (or equivalent) by the hospital administration. About $62.6 \%$ of PPE being disposable; whereas, $59.1 \%$ of N-95 being reused out of which only 32 (26.6\%) N-95 were being re-used according to CDC guidelines.

Forrester et al, reported that developing an algorithm for working of operation theaters in the current pandemic can help improve HCW safety ${ }^{16}$. Other studies alsodescribed various methods used for improving HCW safety and protection against COVID-19 in operating rooms ${ }^{17,18}$. Lakshmi et al. in 2018 reported that in the operating rooms at two tertiary care hospitals; a compliance of $100 \% \mathrm{HCW}$ regarding use of gloves, mask, apron, gown and hair cover whereas goggles as $7.3 \%$ and shoe covers was $8.3 \%$. Even before the pandemic, they reported that $78 \%$ of inappropriate use of PPE was related to its non-availability ${ }^{19}$.

\section{RECOMMENDATION}

We recommend continued improvement in supply as well as training of the HCW regarding safe use of PPE and N-95 as well as hand hygiene.

\section{CONCLUSION}

Most of the operation theaters were providing protective equipment to their staff with nearly half re-using protective gear and N-95 masks.

\section{CONFLICT OF INTEREST}

This study has no conflict of interest to be declared by any author.

\section{REFERENCES}

1. WHO Coronavirus Disease (COVID-19) Dashboard Avalibal at https:// covid19. who.int/?gclid=cjwkcajw5vz2brateiwabcvil7xxj xzmgxi3afrez4eyqctyksxw3srj4ahohzyloehyypwcx0u1lrocdeiqa vd_bwe.

2. Ali S, Noreen S, Farooq I, Bugshan A, Vohra F. Risk assessment of healthcare workers at the frontline against COVID-19. Pak J Med Sci. 2020; 36(Covid-19-S4): COVID-19-S99-S103.

3. COVID-19: Considerations for Optimum Surgeon Protection Before, During, and After Operation. Available at: https:// www.facs.org/covid-19/clinical-guidance/surgeon-protection.

4. Malhotra N, Bajwa SJS, Joshi M. COVID Operation TheaterAdvisory and Position Statement of Indian Society of Anesthesiologist (ISA National). Ind J Anesthesiol 2020; 64(5): 355-62.
5. Rebmann T, Alexander S, Bartley J. APIC position paper: extending the use and/or reusing respiratory protection in health care settings during disasters. Washington, DC: APIC; 2009. Available at: https://apic.org/resource_/tinymcefile-manager/ position_statements/apic_position_ext_the_use_and_or_reus_re sp_prot_in_hlthcare_settings1209l.pdf.

6. Boskoski I, Gallo C, Wallace MB, Costamagna G. COVID-19 pandemic and personal protective equipment shortage: protective efficacy comparing masks and scientific methods for respirator reuse. Gastrointest Endos. 2020; 92(3): 519-23.

7. Hassan S, Sheikh FN, Jamal S. Coronavirus (COVID-19): A review of clinical features, diagnosis, and treatment. Cureus 2020; 12(3): e7355-61.

8. Cook TM. Personal protective equipment during the COVID-19 pandemic - a narrative review. Anaesth 2020; 75(7): 920-27.

9. Tran K, Cimon K, Severn M, Pessoa-Silva CL, Conly J. Aerosol generating procedures and risk of transmission of acute respiratory infections to healthcare workers: a systematic review. Plos One 2012; 7(4): e35797.

10. Rowan NJ, Laffey JG. Challenges and solutions for addressing critical shortage of supply chain for personal and protective equipment (PPE) arising from coronavirus disease (COVID-19) pandemic-case study form Republic of Ireland. Sci Total Environment 2020; 725(1): 138532.

11. Zhang R, Li Y, Zhang AL, Wang Y, M MJ. Identifying airborne transmission as the dominant route for the spread of COVID-19. Available at [Internat]: https://www.pnas.org/lookup/suppl /doi:10.1073/pnas.2009637117/-/DCSupplemental.

12. Fears SC, Klimstra WB, Duprex P, Hartman A, Weaver SC, Plante KS, et al. Persistence of severe acute respiratory syndrome coronavirus 2 in aerosol suspensions. Emerg Infect Dis 2020; 26(9): 2168-71.

13. Jayaweera M, Perera H, Gunawarda B, Manatunge J. Transmission of COIVD-19 virus by droplet and aerosols: a critical review on the unresolved dichotomy. Environ Res 2020; 188(1): 109819-22.

14. Ong SW, Tan YK, Chia PY, Lee TH, Ng OT, Wong MS, et al. Air, surface environmental, and personal protective equipment contamination by severe acute respiratory syndrome coronavirus 2 (SARS-CoV-2) from a symptomatic patient. JAMA 2020 Mar 4 [Epub ahead of print]. Available at [Internet]: https:// jamanetwork.com/journals/jama/fullarticle/2762692.

15. MacIntyre CR, Chughati AA. A rapid systematic review of the efficacy of face masks and respirators against coronaviruses and other respiratory transmissible viruses for the community, healthcare workers and sick patients. Int J Nur Stud 2020; 108(2): 103629-32.

16. Forrester JD, Nassar Ak, Maggio PM, Hawn MT. Precautions for operating room team members during The COVID-19 Pandemic. J Am Chem Soc 2020; 230(6): 1098-01.

17. Cheung EHL, Chan TCW, Wong JWM, Abd Law MS. Sustainable response to the COVID-19 pandemic in the operating theaters: we need more than just personal protective equipment. Br J Anaesth 2020; 125(2): e242-44.

18. Wong J, Goh QY, Tan Z, Lie SA, tay YC, Ng SY, et al. Preparing for a COVID-19 pandemic: a review of operating room outbreak response measures in a tertiary hospital in Singapore. Can J Anaesth 2020: 67(6): 732-45.

19. Lakshmi PA, Jennifer HG, Stanly AM. A study on personal protective equipment use among health care providers, Tamil Nadu. Int J Community Med Public Health 2018; 5(5): 1771-7. 